\title{
EVOLUTION OF GENRE PARAMETERS OF DOCUMENTARY TEXT (EXEMPLIFIED BY REFERENCES)
}

\author{
Olga A. Nosacheva \\ Volgograd State University, Volgograd, Russia
}

\begin{abstract}
The article considers reference as an information-and-assessment document, the dynamics of reference transformation is viewed from documentary linguistics angle. The research is carried out on the material of reference given to applicants in the field of education; the documents belong to different chronological periods (Soviet period (wartime): 1941-1945; Soviet period: 1970-1990s; modern period: 2015-2020). The functional purpose of the document was determined and the composition and content structure of its text was analyzed. Speech means representing the main genre characteristics of the text of reference have been identified; they are presented at three levels of the hierarchy, taking into account their interconnection and significance as genre-forming parameters: addresser/addressee and function; information, structure and dominant modality; space and time. The author reveals the regularities of text formation, as well as genre peculiarities of the text, determined by social and linguistic factors. When analyzing the genre parameters of the document, the fact that the properties of the text are influenced by the specifics of the communication situation is taken into account. It was shown that social changes caused a shift in the nature of the information transmitted by the document; affected the structure and dominant modality of the text, space and time representation. Extralinguistic determination of speech organization of documentary text is demonstrated. It was established that speech representation of genre parameters is associated with the implementation of informational and presentation functions of the document.

Key words: genre, genre parameters, document, document properties, dynamics of the genre, reference.

Citation. Nosacheva O.A. Evolution of Genre Parameters of Documentary Text (Exemplified by References). Vestnik Volgogradskogo gosudarstvennogo universiteta. Seriya 2. Yazykoznanie [Science Journal of Volgograd State University. Linguistics], 2021, vol. 20, no. 1, pp. 134-145. (in Russian). DOI: https://doi.org/ 10.15688/jvolsu2.2021.1.11
\end{abstract}

\section{ДИНАМИКА ЖАНРОВЫХ ПАРАМЕТРОВ ДОКУМЕНТНОГО ТЕКСТА (НА МАТЕРИАЛЕ ХАРАКТЕРИСТИКИ)}

\author{
Ольга Александровна Носачева \\ Волгоградский государственный университет, г. Волгоград, Россия
}

\begin{abstract}
Аннотация. В статье с позиций документной лингвистики рассматривается динамика характеристики как информационно-оценочного документа. На материале характеристик, использующихся в сфере образования, разных хронологических периодов (советский период (военное время): 1941-1945 гг; советский период: 19701990-е гг; современный период: 2015-2020 гг.) определено функциональное назначение документа и проанализирована композиционно-содержательная структура его текста. Выявлены речевые средства репрезентации основных жанровых параметров текста характеристики, которые представлены на трех уровнях иерархии с учетом их взаимосвязанности и значимости как жанрообразующих: адресант / адресат и функция; информация, структура и доминирующая модальность; пространство и время. Установлены жанровые особенности текста, детерминированные социальными и лингвистическими факторами, закономерности формирования текста документа. При анализе жанровых параметров документа учитывается тот факт, что на свойства текста оказывает влияние специфика ситуации общения. Показано, что социальные изменения обусловили измене-
\end{abstract}


ние характера передаваемой документом информации, структуры и доминирующей модальности текста, оформления пространственно-временных координат; продемонстрирована экстралингвистическая детерминированность речевой организации документного текста. Доказано, что речевая репрезентация жанровых параметров связана с реализацией информационной и презентационной функций документа.

Ключевые слова: жанр, параметры жанра, документ, свойства документа, динамика жанра, характеристика.

Цитирование. Носачева О. А. Динамика жанровых параметров документного текста (на материале характеристики) // Вестник Волгоградского государственного университета. Серия 2, Языкознание. - 2021. T. 20, № 1. - C. 134-145. - DOI: https://doi.org/10.15688/jvolsu2.2021.1.11

\section{Введение}

Проблема жанровой принадлежности текста, типологии жанров, их релевантных признаков, несмотря на большое внимание, которое ей уделялось в лингвистике, продолжает оставаться одной из дискуссионных. Особую значимость она приобретает для документного текста, который имеет свою функциональную, композиционно-содержательную и речевую специфику.

В рамках исследований документного текста, проводимых учеными Волгоградского государственного университета, используется модель анализа жанра Т.В. Шмелевой [Шмелева, 1997] (термины «жанр» и «вид» по отношению к документному тексту мы употребляем как синонимы), но видоизмененная, уточненная с учетом специфики документного текста. В основу модели положены несколько параметров жанра: субъекты коммуникации (адресант, адресат), функция документа, характер передаваемой информации, структура, доминирующая модальность, пространственно-временная локализация (параметры «пространство» и «время»), которые взаимодействуют между собой [Горбань и др., 2016]. Указанные параметры имеют разную значимость для организации текста, что позволяет распределить их по трем иерархическим уровням.

К первому уровню иерархии относятся параметры «адресант / адресат» и «функция». Особенности субъектов коммуникации, их социальный статус во многом определяют коммуникативную цель, а значит, функцию документа и выбор жанра.

На втором уровне находятся параметры «информация», «структура» и «модальность».

Коммуникативная задача адресанта обусловливает характер информации, которая в свою очередь детерминирует структуру документа - взаимосвязь элементов, обеспечивающую его целостность. Функция и субъекты коммуникации определяют доминирующую модальность документного текста отношение автора к сообщаемому, выраженное в тексте, его коммуникативную установку, а также устанавливаемое им отношение сообщаемого к действительности.

К третьему уровню относятся параметры «пространство» и «время».

Информация, переданная в документе, существует в системе пространственновременных координат, что предопределяет наличие этих параметров. Однако пространственная локализация косвенно детерминирована параметрами предыдущих уровней: она может зависеть от адресанта и адресата текста (в тексте может содержаться указание на их местоположение), от функции документа (функции конкретного документа нередко ограничиваются определенной территорией или частью социума), от структуры (если в документе имеется реквизит «место создания документа»). Временная отнесенность документа также косвенно обусловлена структурой документа (излагаемые события в композиционных блоках документа могут иметь разную временную отнесенность) и зависит от модальности (объективная модальность проявляется через временную отнесенность событий).

Анализируя жанровые параметры документа, мы рассматриваем его не только как самостоятельный, вычлененный для анализа, «изолированный» научный объект, но и как элемент социальной деловой коммуникации, а следовательно, учитываем тот факт, что на свойства текста оказывает влияние специфика ситуации общения, экстралингвистические факторы. 


\section{МАТЕРИАЛЫ И СООБЩЕНИЯ}

С позиций данного подхода рассмотрим динамику такого документа, как характеристика, который активно используется в разное время и определяется как «документ, содержащий комплексную оценку профессиональных и личностных качеств работника, выявленных за время его работы на данном предприятии, а также выводы и предложения по его перспективной карьерной траектории» [Токарев, 2010, с. 46], «официальный документ, содержащий отзыв, заключение о чьей-либо трудовой и общественной деятельности» (БТС). Характеристика «выдается сотруднику администрацией учреждения, организацией в ряде ситуаций (выдвижение на выборную должность, избрание по конкурсу на работу, поступление в учебные заведения, запросы сторонних организаций - суда, военкомата и т. п.) и содержит отзыв о служебной и общественной деятельности сотрудника, оценку его деловых и моральных качеств» [Колтунова, 2000].

В зависимости от назначения выделяют несколько видов характеристик: «представление - необходимо при аттестации, принятии решения о поощрении, назначении работника на другую должность и т. д.; отзыв - требуется как ответ на запросы государственных, правоохранительных и иных органов, сторонних организаций; при применении мер дисциплинарного взыскания и т. д.; рекомендация может оформляться при смене места работы; при переводе в другую организацию и т. д.» [Тарасов, 2017].

Цель настоящего исследования заключается в выявлении жанровой специфики характеристики как информационно-оценочного документа, закономерностей формирования его текста.

\section{Материал и методы}

Материалом для анализа послужили характеристики учителей школы. Исследуемые документы имеют разную хронологическую отнесенность.

Условно были выделены три хронологических периода, которые отличаются особыми политическими и социальными условиями:

1) советский период (военное время): 1941-1945 гг. (рассматриваются документы
ГКУВО «Государственный архив Волгоградской области», в частности характеристики учителей школ Сталинградской области 19411945 гг. - Калачевской неполной средней школы, Калачевской средней школы, Ляпичевской средней школы и Голубинской средней школы (Ф. 3423. Оп. 3. Ед. хр. 2. С. 15-19). В материалах архивного фонда представлены характеристики только одного вида - характеристика-отзыв, которую директор школы или руководитель отдела народного образования давал по запросу специального ведомства;

2) советский период: 1970-1990-е гг. (рассматриваются документы ГБПОУ «Волгоградский строительный техникум» 19701990-х гг.). Основным видом характеристики являлась характеристика-представление, которая была необходима для аттестационной комиссии, решающей вопрос о повышении категории учителя;

3) современный период: 2015-2020 гг. (рассматриваются электронные документы, в частности характеристики учителей школы 2015-2020 гг.). В настоящее время используются различные виды документов: характеристика-представление, характеристикапросьба, характеристика-поощрение и др. Объектом нашего анализа, как и во второй период, стала характеристика-представление.

Для жанровой идентификации документов, как правило, используются несколько методов, применение которых позволяет выявить разновидности документных текстов и описать их основные свойства [Косова, 2017]. В настоящей работе основным методом стал анализ модели жанровых параметров. Этот метод анализа документного текста опирается на положения, представленные в работах многих авторитетных ученых (М.M. Бахтина [1979], В.В. Дементьева [2015], В.Е. Гольдина, О.Н. Дубровской [2002], М.Ю. Федосюк [1997], Т.В. Шмелевой [1997] и др.). Полученные учеными результаты имеют не только теоретическую ценность, дополняя сведения о документе как лингвистическом объекте, его стилевой организации и др., но и практическое значение - они раскрывают механизм создания и использования документов в различных сферах деловой коммуникации. Однако все возрастающая роль документов в современном обществе, преобразование уже суще- 
O.А. Носачева. Динамика жанровых параметров документного текста (на материале характеристики)

ствующих документов и появление новых делают актуальным вопросы о закономерностях их формирования, о становлении жанровых признаков документного текста, о факторах, которые обусловливают эти процессы.

В работе использовались и другие методы - сравнительного, семантического и стилистического анализа.

\section{Результаты и обсуждение}

\section{Характеристика в советский период (военное время)}

1941-1945 гг. - тяжелое военное время, и оно требовало особого внимания к тем людям, в том числе и учителям школы, «кто имел дореволюционный стаж работы, непролетарское происхождение, кто находился ранее на оккупированной территории» [Васильковская, 2006].

Рассмотрим жанровые параметры разных уровней и их реализацию в тексте документа.

\section{Параметры «адресант / адресат», «функичия»}

Адресант характеристики является единичным, персонифицированным и репрезентирован в реквизите «подпись», в состав которого входят наименование должности лица, его личная подпись и расшифровка подписи: $\partial u$ ректор Калачевской средней школь Щукарева Анна Ивановна, зав. РОНО + подпись.

Адресат в тексте документа имплицирован. Однако из исторических источников известно, что адресатом было специальное ведомство, в частности орган государственной безопасности СССР - оперативные группы НКВД и ЧГК, от которых поступал запрос руководству школы [Васильковская, 2006]. Представляя собой ответ на такой запрос, характеристика сообщала сведения (информацию) об учителе и таким образом выполняла информационную функцию.

Параметры «информацияя, «структура», «доминирующая модальность»

Характеристика военного времени сообщала фактуальную информацию, то есть дос- товерные, подтверждаемые сведения о работе учителя: Кирьянова А.И. работает учителем в Калачевской неполной средней школе с 9 января 1943 года. Таких сведений, однако, было немного. Основное содержание составляла оценка профессиональных и личностных качеств педагога. Обратим внимание на то, что в рассмотренных документах преобладает отрицательная оценка деятельности учителя школы, различных аспектов его работы: учебно-методической (плохо проводились уроки арифметики; некоторые учителя плохо готовились к урокам и качество проведения неудовлетворительно; не проверялись работы учашихся; не организовано взаимное посещение занятий и их анализ); воспитательной (воспитательная работа поставлена неудовлетворительно, не была спланирована; не ведет учета; недостаточно удачно подбирает материал к художественным выступлениям; план работы не имеет; отсутствуют элементы воспитания патриотизма); общественной (общественная работа выполнялась недостаточно; не принимает никакого участия; не помогает). Негативно оценивались и личностные качества учителя: проявляет большое высокомерие; пренебрежительный тон к учащимся; очень хитер; проявляет стремление выставить в невыгодном свете «новое руководство». Положительная оценка представлена в документе незначительно: предмет свой т. Трунин знает хорошо; уроки проводит живо; документация - планы, списки учащчихся в полном порядке.

Параметр «структура» отражает важное для документного текста свойство, так как логически организует информацию. В рассматриваемых текстах можно выделить три композиционно-содержательные части.

Первая часть включает наименование документа: «Характеристика на учительнииу Калачевской средней школь Кирьянову Александру Ильиничну» - и должность учителя, на которого пишется характеристика: тов. Трунин В.И., учитель математики и физики в Калачевской средней школе; Попов А.Д., преподаватель математики в Ляпичевской средней школе; Брандт Е.С., завуч в Голубинской средней школе; Кирья- 


\section{МАТЕРИАЛЫ И СООБЩЕНИЯ}

нова А.И, учительница начальных классов в Калачевской неполной средней школе.

Вторая часть - это основные сведения о работе педагога. Отметим, что содержание этой части не имеет однотипной организации, сведения излагаются в свободной форме.

Третья часть включает информацию о дате написания документа, ФИО писавшего, его должности, а также печать организации: 24 января 1944 г., директор Калачевской средней школь Щукарева Анна Ивановна; 23 января 1944 г., директор школы М. Фетисов.

Иерархия адресанта и адресата, их разный статус определяют речевую реализацию параметра «доминирующая модальность текста». Документы рассматриваемого периода отличает объективная модальность реальности и ситуативная модальность сообщения или осведомления.

\section{Параметры «пространство» и «время»}

Параметр «пространство» реализуется в тексте именами собственными и нарицательными, обозначающими в тексте учебные заведения: Калачевская неполная средняя школа; Голубинская средняя школа. Параметр «время» репрезентирован реквизитом «дата документа», который оформлялся поразному: 23/1.44 г.; 12 октября 1943 года.

Анализ речевой организации текста характеристик выявил их стилевую неоднородность, что можно объяснить прежде всего экстралингвистическими причинами: в условиях военного времени должность директора школы нередко занимали те, кто не имел ранее такого опыта и не владел в полной мере нормами делового стиля. Так, в тексте отмечаются отдельные черты официальноделового стиля, в частности использование отглагольных существительных (невыполнение решений; налаживание работы), расчлененных сказуемых (проявляет стремление; принимает участие; развернуть рабоmy), речевых штампов (работа поставлена слабо; подрывает авторитет руководства школь), безличных инфинитивных предложений (на репетищиях бывать ей некогда; невозможно отрицать прошлый опыт классного руководства; следует отмети- ть в работе следующий недостаток), но также элементы разговорного стиля (являлась руководительницей; учительница Кирьянова; он «сам себе на уме»; ярко вырисовывается; не хочется повторять; не всем дано справляться с детьми; и вообще воспитательная работа поставлена слабо).

Текст, его единицы отражают реалии того времени, связанные с организацией школьного обучения: уроки арифметики, списки учащихся, записи посещения уроков, оценка знаний учащихся во внеурочное время, воспитание патриотизма и др., а часто и непростую социальную обстановку: Проявляет стремление выставить в невыгодном свете новое руководство на педсовете или, еще хуже, среди учителей, в отсутствие директора, что является «подсиживанием», желанием подорвать авторитет руководства школь; Во время оккупации немиами т. Трунин находился в станиие Голубинская, о его поведении в этот период ничего сказать не могу, т.к. я эвакуировалась в Саратовскую область и вернулась в Калач в октябре 1941 года.

\section{Характеристика в советский период}

1970-1990-е гг. - период развития различных социальных сфер и институтов советского государства, в том числе и образования. В это время важную роль играют институты усовершенствования учителей как научно-методические центры повышения педагогического мастерства работников образования, обобщения и распространения передового педагогического опыта.

Рассмотрим жанровые параметры текста документа.

\section{Параметры «адресант / адресат», «функиия»}

Адресант характеристики репрезентирован в реквизите «подпись». Как правило, характеристику давала комиссия, в этом случае адресант был коллективным и персонифицированным: Председатель ГОРКОМА Р. Папилов, секретарь парторганизаџии М. Коган, председатель МЕСТКОМА М. Серова. 
Адресат в тексте имплицирован, однако иерархия учреждений системы образования и процедура повышения категории учителя предполагали, что характеристики такого вида представляли собой определенного рода обращение в государственную структуру, которая занимается подготовкой кадров в системе дополнительного профессионального педагогического образования [Худоминский, 1986].

Назначение характеристики и ее содержание позволяют говорить о том, что документ данного периода выполняет не одну функцию. Набор функций документа, как отмечает М.В. Косова, представляет собой величину непостоянную, динамическую: со временем под влиянием разного рода факторов некоторые функции документа могут стать незначимыми, и наоборот, документ может приобретать новые, актуальные функции [Косова, 2016, с. 9]. Характеристика реализует информационную и презентационную функции адресант описывает заслуги педагога и рекомендует его на более высокую должность. Реализация презентационной функции в тексте «предполагает отбор важных признаков объекта характеристики с учетом индивидуального восприятия для целей влияния и воздействия в процессе коммуникации» [Олянич, 2015, c. 149].

Параметры «информачия», «структура», «доминирующая модальность»

В характеристике представлены достоверные сведения о деятельности педагога, которые выражены в тексте вербальноцифровыми единицами, обозначениями пространственно-временных дат: в 198081 учебном году Зайцевой Н.М. написана методическая разработка на тему: «Повышение эффективности обучения на уроке английского языка с помощью средств наглядности и технических средств»; в 1979-80 уч. году была избрана секретарем педагогического совета и членом штаба по предупреждению правонарушений; в 1980-81 г2. являлась членом штаба соревнования при ученическом профкоме. Кроме того, содержится оценка деятельности учителя. Отметим, что в рассмотренных характеристиках выражена прежде всего по- ложительная оценка: хорошо знающий и владеющий программным материалом преподаватель, умеющий при желании очень доходчиво, просто, образно доносить знания до обучающихся; проводит большую индивидуальную работу с учашимися и с активом группь; за время работы Нина Максимовна показала себя высококвалифицированным, добросовестным специиалистом. При этом говорится и об отдельных недостатках, что, вероятно, обусловлено стремлением к объективности: несистематически ведется кружковая работа дополнительных занятий и консультации; недостатком в работе является неактивное участие в подготовке и проведении общественных мероприятий; макеты выполняются на низком уровне; недостаточно дисциплинированна, были случаи опоздания на уроки, неявки на заседание ичикловой комиссии, может допускать элементы бестактности; недостаточно работает в группе по укреплению учебной дисциплины, борьбы с правонарушениями у учащихся и активности; не всегда участвует в выставке технического творчества; и высказываются пожелания: необходимо более активное включение в работу КНД, оказывая помощь руководителю; активировать работу кружкка английского языка и др.

В отличие от характеристики военного времени, документ второго периода имеет строгую композиционно-содержательную структуру.

Первая часть включает реквизиты «наименование организации», «место составления или издания документа»: Государственное бюджетное профессиональное образовательное учреждение «Волгоградский строительный техникум»; «наименование вида документа»: характеристика на преподавателя сантехники Звереву Элеонору Михайловну.

Вторая часть - это основной текст. Она содержит анкетные данные (год рождения, национальность, партийность, образование, стаж работы): 1940 года рождения, русская, б/партийная, общий стаж работы 19 лет; Э.М. Зверева 1935 года рождения, в 1958 году окончила Сталинградский институт инженеров городского хозяйства 
по специальности инженер-строитель сантехнических устройств; непедагогический стаж 23 года; описание профессиональных и личностных качеств преподавателя.

Третья часть текста содержит резолюцию, связанную с видом характеристики, ее коммуникативной целью: соответствует занимаемой должности; комиссия рекомендует аттестовать Митину Т.Н. на высшую квалификационную категорию; реквизиты «наименование должности лица - автора документа»и «подпись»: председатель ичикловой комиссии Бобрикова Д.И.; председатель ГОРКОМА Р. Папилов, секретарь парторганизации М. Коган, председатель МЕСТКОМА М. Серова; «оттиск печати» и отметку об ознакомлении: с характеристикой ознакомлена Зверева Э.М.

Текст документов рассматриваемого периода отличает объективная модальность реальности, при этом подчиненное положение адресанта и нацеленность на побуждение к принятию решения адресатом обусловливают ситуативную модальность сообщения и необязательного предписания: coответствует занимаемой должности при условии устранения отмеченных замечаний.

\section{Параметры «пространство» и «время»}

Параметр «пространство» реализуется в тексте собственными и нарицательными именами существительными, обозначающими учреждения образования, в реквизите «наименование организаций»: Волгоградский строительный техникум; характеристика утверждена на педагогическом совете техникума, протокол № 7. Параметр «время» репрезентирован реквизитом «дата составления документа», который во всех документах оформлялся одинаково: 16 марта 1970 г., 23 июля 19812.

Тексты рассмотренных документов соответствуют нормам официально-делового стиля: отмечается использование отглагольных существительных (повыщение эффективности; прививание навыков; предупреждение правонарушений), сложных слов, образованных от двух и более основ (самообразование; высококвалифицированный; добросовестныці; идейно-теоретический уровень), производных предлогов (на основании заключения аттестационной комиссии), речевых штампов (работа выполняется на низком уровне; шествовала над учашимися; необходимо более активно включаться в работу; были случаи опоздания на уроки; недобросовестное отночение); безличных инфинитивных предложений (необходимо доносить знания до учащихся, необходимо было активизировать работу Э.М. Зверевой; обдумывать действия было уже некогда).

В текстах встречаются единицы, маркирующие советский период: беспартийная; работа в КНД; партийно-комсомольское собрание, посвященное 111 годовщине со дня рождения В.И. Ленина; агитатор; ученический профком; избрана секретарем педагогического совета.

\section{Характеристика в современный период}

Период 2015-2020 гг. - время современного образовательного процесса, когда ведутся поиски новых технологий, которые можно применять в педагогической деятельности. Внедрение информационно-коммуникационных технологий (далее - ИКТ) открывает значительные возможности расширения образовательных рамок по каждому предмету. Переход к новой системно-деятельностной образовательной парадигме связан с принципиальными изменениями работы учителя, реализующего новый стандарт.

Рассмотрим параметры текста характеристики-представления.

\section{Параметры «адресант / адресат», «функция»}

Адресант характеристики может быть как единичным (в этом случае он персонифицированный): директор МОУ СОШ № 9 Buнокурова И.А., так и коллективным (в этом случае он неперсонифицированный): педагогический коллектив МАОУ СООШ №23 города Томска.

Адресатом характеристики является официальная вышестоящая по отношению к адресанту организация сферы образования. В тексте он обозначен отдельным реквизитом, 
O.A. Носачева. Динамика жанровых параметров документного текста (на материале характеристики)

например: представительство Милославского района, начальнику управления образования администрации Советского мунииипального района Ставропольского края Пахмутовой Т. П.

В предыдущем периоде адресат не обозначен как отдельный реквизит, представлен имплицитно. Характеристика в данный период, как и в советское время, выполняет информационную и презентационную функции.

Параметры «информация», «структура», «доминирующая модальность»

Характеристика рассматриваемого периода содержит подтвержденные, достоверные сведения о заслугах педагога, что, как и в документах предыдущего периода, выражено вербально-цифровыми единицами, обозначениями пространственно-временных дат: 23 ноября 2008 года провела семинарское занятие по теме: "Использование ИКТ и ЦОР на уроках истории»; Н.В. Власкиной присвоена первая квалификационная категория по должности «Учитель» 28.12.2012 года, приказ Министерства образования Рязанской области от 17.01.20132. №24-A; Оксане Сергеевне были объявлены благодарности за участие в научно-практической конференции «Воспитание личности и преподавание духовно-нравственных курсов...» (2011 год), за подготовку учашихся $\kappa$ муниципальному этапу Всероссийской олимпиады школьников (2011, 2012 гz.), за подготовку побудителя конкурса "Храни себя, Святая Русь!» (2013 год).

В тексте характеристики дается оценка профессиональным и личностным качествам учителя: за время работы Ирина Владимировна зарекомендовала себя как грамотный педагог, обладающий высоким уровнем мастерства, стремящийся совершенствовать свои профессиональные навыки; отвечает всем требованиям, предъявляемым к учителю; знание предмета. Оценка, как правило, только положительная, и выражена она в тексте клишированными выражениями, что говорит о формализации текста и «угасании» информативной функции.

Презентационная функция, наоборот, актуализируется. В документе эксплицирована положительная оценка профессиональных качеств учителя: изучает и анализирует опыт коллег; обладает аналитическим мылилением, применяет в работе современные педагогические технологии продуктивного, дифференцированного обучения; реализаиия развивающего обучения; владеет методикой системного анализа урока, методикой дифференцированного и индивидуального обучения, навыками личностноориентированного и деятельностного подхода в обучении; его личностных качеств: учитель пользуется авторитетом и уважением коллег по работе, родителей; опытный, требовательный педагог; незаурядная, творческая, энергичная личность, имеющая педагогический и организаторский талант, чуткая и внимательная во взаимоотношениях с коллегами. Недостатки не отмечаются.

В структуре характеристики этого периода можно выделить три композиционносодержательные части.

Первая часть включает реквизиты «наименование организации», «место составления или издания документа»: Муниципальное общеобразовательное учреждение "БольшеПодовеченская школа» Милославского района; муниципальное образовательное учреждение средней общеобразовательной школь №9; «наименование вида документа»: Характеристика Игнатовой Валентины Михайловны, учителя начальных классов; характеристика-представление преподавателя русского языка и литературы Костиной Татьяны Алексеевны.

Вторая часть включает анкетные данные (ФИО педагога, год рождения, национальность, образование, должность, стаж работы): Власкина Н.В, учитель математики и физики, Бровкина Г.А., учитель истории и географии, Петрюк Ольга Ивановна, учитель начальных классов; Бодрова И.В., учитель русского языка и литературы; 1965 года рождения, высшее образование, стаж 25 лет; 11 мая 1982 года рождения, общий педагогический стаж 7 лет; стаж 38 лет; здесь же содержится описание профессиональных и личностных качеств учителя.

Третья часть содержит вывод - рекомендацию / представление, связанные с ком- 


\section{МАТЕРИАЛЫ И СООБЩЕНИЯ}

муникативной целью характеристики: $а д м и-$ нистрация рекомендует Костину Т.А. к аттестации на высшую квалификационную категорию, директор Н.В. Балашов; рекомендуется к аттестации на первую квалификационную категорию, директор средней общеобразовательной школь при войсковой части 2393 Э.Г. Айрапетян.

В этой части содержатся реквизиты «отметка об ознакомлении» и «подпись»: $c x a$ рактеристикой ознакомлена Сергеева Л.Н., c представлением ознакомлена Власкина Н.В., с представлением ознакомлена О.И. Петрюк; директор МОУ СОШ № 9 Винокурова И.А., директор МОУ «СОШ № 8 с. Горькая Балка» Л.Н. Белоусова. Документы заверяются печатью организации.

В документах рассматриваемого периода доминирует объективная модальность реальности и ситуативная модальность сообщения и необязательного предписания: администрачия Зубово-Полянского педагогического колледжа рекомендует Костину Татьяну Алексеевну к аттестации на высшую квалификаиионную категорию.

\section{Параметры «пространство» и «время»}

Параметр «пространство» реализуется именами собственными и нарицательными, обозначающими наименования учреждений образования в реквизите «наименование организации»: Милославская, Горняикая, Шолинская основная общеобразовательная школа, Средняя общеобразовательная школа № 1 имени П.И. Омельченко Лесозаводского городского округа; а также топонимами в реквизите «подпись»: начальник управления образования администрации Советского муниципального района Ставропольского края Пахмутова Т. П.

Параметр «время» репрезентирован реквизитом «дата документа», который оформляется уже единообразно: 10.03.2018 г., 18.04.2020 г.

Текст документов данного периода соответствует нормам официально-делового стиля: используются отглагольные существительные (принятие решений; формирование навыков; стремление к проявлению методического мастерства), слож- ные слова (самоорганизация; доброжелательный; информационно-коммуникативные технологии), речевые штампы (coomветствует требованиям; вопрос освещен; можно ознакомиться с ее разработ$\kappa a м и)$, безличные инфинитивные предложения (необходимо было распределить задания между учениками; нужно было учитывать особенности памяти и мымления детей).

В тексте представлены номинации, отражающие новый уровень системы образования: диплом за организацию сверхпрограммной общероссийской предметной олимпиады Олимпус; присуждена именная стипендия Главы администрации; благодарность за участие в проверке всероссийских проверочных работ, в научно-практической конференции; эффективное использование здоровьесберегающих технологий, дифференцированного обучения; владеет предметнометодической, психолого-педагогической и ИКТ компетенциями.

\section{Заключение}

Таким образом, совокупность жанровых параметров, особенности их речевого выражения позволяют рассматривать характеристику как социально детерминированный вид документа, выполняющего информационную и презентационную функции. Изучение документов разных периодов позволило выявить изменения характера передаваемой документом информации, структуры и доминирующей модальности текста, оформления пространственно-временных координат, продемонстрировать экстралингвистическую обусловленность речевой организации документного текста, закономерности формирования жанра характеристики, определяемые социальными и лингвистическими факторами.

\section{СПИСОК ЛИТЕРАТУРЫ}

Бахтин М. М., 1979. Проблема речевых жанров // Эстетика словесного творчества. М. : Искусство. C. 237-280.

Васильковская Е. И., 2006. Власть и формирование советской модели школьной системы (нача- 
ло 1930-х - начало 1950-х гг.) : дис. ... канд. ист. наук. Саратов. $251 \mathrm{c}$.

Гольдин В. Е., Дубровская О. Н., 2002. Жанровая организация речи в аспекте социальных взаимодействий // Жанры речи. Саратов : Колледж. Вып. 3. С. 5-17.

Горбань О. А., Ильинова Е. Ю., Косова М. В., Шептухина Е. М., 2016. Жанровые особенности войсковых грамот середины XVIII в. (по материалам архивного фонда «Михайловский станичный атаман») // Известия Уральского федерального университета. Серия 2, Гуманитарные науки. Т. 18, № 4 (157). С. 182-199. DOI: 10.15826/izv2.2016.18.4.074.

Дементьев В. В., 2015. Теория речевых жанров и актуальные процессы современной речи // Вопросы языкознания. № 6. С. 78-107.

Драчук Н. В., Черницына Т. В., 2015. Характеристика как жанр официально-делового стиля // Евразийский союз ученых. № 4-8. С. 44- 47.

Колтунова М. В., 2000. Язык и деловое общение : Нормы. Риторика. Этикет. М. : Экономика. URL: https://www.vib33.ru/upload/information system_19/1/0/4/item_104/koltunova_language_ business_communications.doc (дата обращения: 02.03.2020).

Косова М. В., 2016. Метод документоведческого анализа в лингвистических исследованиях: содержание и цели // Вестник Волгоградского государственного университета. Серия 2, Языкознание. № 1. C. 7-17. DOI: http://dx.doi. org/10.15688/jvolsu2.2016.1.1.

Косова М. В., 2017. Динамика жанровых параметров региональных документов XVIII века // Текст в языке, речи, культуре : сб. науч. ст. Минск : РИВШ. С. 123-134.

Олянич А. В., 2015. Презентационный дискурс // Научный журнал «Дискурс-Пи». Вып. 3-4. C. $148-150$.

Тарасов М. Е., 2017. Характеристика - анахронизм или реальность? // Секретарь-референт. № 12. URL: https://www.profiz.ru/sr/12_2017/charakteristika (дата обращения: 02.03.2020).

Токарев Г. В., 2010. Документная лингвистика. Тула : Арт-принт. 125 с.

Федосюк М. Ю., 1997. Нерешенные вопросы теории речевых жанров // Вопросы языкознания. № 5. С. 102-120.

Худоминский П. В., 1986. Развитие системы повышения квалификации педагогических кадров советской общеобразовательной школы (19171981 гг.). М. : Педагогика. 182 с.

Шмелева, Т. В., 1997. Модель речевого жанра // Жанры речи. Саратов : Изд-во Гос. учеб.науч. центра «Колледж». С. 88-98.

\section{ИСТОЧНИКИ И СЛОВАРИ}

БТС - Большой толковый словарь русского языка / гл. ред. С. А. Кузнецов. СПб., 1998. Публ. в авт. ред. 2014 года. URL: http://gramota.ru/ slovari/info/bts/ (дата обращения: 04.03.2020).

ИНФОУРОК. URL: https://infourok.ru/predstavleniena-pervuyu-kvalifikacionnuyu-kategoriyu2322411.html (дата обращения: 04.03.2020).

Компрометирующий материал на учителей Сталинградской области, бывших на оккупированной территории // Государственный архив Волгоградской области. Ф. 3423. Оп. 3. Ед. хр. 2. C. 15-19.

Личные дела преподавателей // Архив ГБПОУ «Волгоградский строительный техникум» 19701990 гг.

Педагогическое сообщество «УРОК.РФ». URL: https://урок.pф/library/materiali_dlya_ attestatcii/harakteristika_pedagoga (дата обращения: 04.03.2020).

УМК СПО. URL: http://atestat.umk-spo.biz/articles/ zapdok/teorija/primer/primerxarrys (дата обращения: 04.03.2020).

Videouroki.net. URL: https://videouroki.net/razrabotki/ kharaktieristika-uchitielia-nachal-nykh-klassov. html (date of access: 04.03.2020).

\section{REFERENCES}

Bakhtin M.M., 1979. Problema rechevykh zhanrov [The Problem of Speech Genres]. Estetika slovesnogo tvorchestva [Esthetics of Verbal Creativity]. Moscow, Iskusstvo Publ., pp. 237-280.

Vasilkovskaya E.I., 2006. Vlast i formirovanie sovetskoi modeli shkolnoi sistemy (nachalo 1930-kh nachalo 1950-kh gg.): diss ... kand. ist. nauk [Power and the Formation of the Soviet Model of the School System: Early 1930s - Early 1950s. Cand. of hist. sci. diss.]. Saratov. $251 \mathrm{p}$.

Goldin V.E, Dubrovskaya O.N, 2002. Zhanrovaya organizatsiya rechi $\mathrm{v}$ aspekte sotsial'nykh vzaimodejstvij [Genre Organization of Speech in the Aspect of Social Interactions]. Zhanry rechi [Genres of Speech]. Saratov, Kolledzh Publ., iss. 3, pp. 5-17.

Gorban O.A., Ilyinova E.Yu, Kosova M.V., Sheptukhina E.M., 2016. Zhanrovye osobennosti voyskovykh gramot serediny XVIII v. (po materialam arkhivnogo fonda «Mikhaylovskiy stanichnyy ataman») [Genre Characteristics of the $18^{\text {th }}$ Century Military Charters (With References to the Archival Fund of Mikhailovsky Stanitsa Ataman)]. Izvestiya Uralskogo federalnogo 
universiteta. Seriya 2. Gumanitarnyye nauki [Izvestia. Ural Federal University Journal. Series 2. Humanities and Arts], vol. 18, no. 4 (157), pp. 182 199. DOI: 10.15826/izv2.2016.18.4.074.

Dementyev V.V, 2015. Teoriya rechevykh zhanrov i aktual'nye protsessy sovremennoj rechi [The Theory of Speech Genres and Actual Processes of Modern Speech]. Voprosy yazykoznaniya [Topics in the Study of Language], no. 6, pp. 78-107.

Drachuk N.V., Chernitsyna T.V., 2015. Kharakteristika kak zhanr ofitsialno-delovogo stilya [Characteristics as a Genre of Official Business Style]. Evraziyskiy soyuz uchenykh [Eurasian Union of Scientists], no. 4-8, pp. 44-47.

Koltunova M.V., 2000. Iazyk i delovoe obshchenie: Normy. Ritorika. Etiket [Language and Business Communication: Norms. Rhetoric. Etiquette]. Moscow, Ekonomika Publ. URL: https://www.vib33.ru/upload/information system_19/1/0/4/item_104/koltunova language_business_communications.doc (accessed 2 March 2020).

Kosova M.V,2016. Metod dokumentovedcheskogo analiza v lingvisticheskikh issledovaniyakh: soderzhanie i tseli [The Method of Documentary Analysis in Linguistic Research: Content and Goals]. Vestnik Volgogradskogo gosudarstvennogo universiteta. Seriya 2, Yazykoznaniye [Science Journal of Volgograd State University. Linguistics], no. 1, pp. 7-17. DOI: http://dx.doi.org/10.15688/jvolsu2. 2016.1.1.

Kosova M.V., 2017. Dinamika zhanrovykh parametrov regionalnykh dokumentov XVIII veka [Dynamics of Genre Parameters of the Regional Documents of the $18^{\text {th }}$ Century]. Tekst vyazyke, rechi, kulture: sb. nauch. st. [Text in Language, Speech, Culture. Collected Articles]. Minsk, RIVSh, pp. 123-134.

Olyanich A.V., 2015. Prezentatsionnyy diskurs [Presentation Discourse]. Nauchnyy zhurnal «Diskurs-Pi» [Scientific Journal "DiscoursePi’'], iss. 3-4, pp. 148-150.

Tarasov M.E., 2017. Kharakteristika - anakhronizm ili realnost? [Characteristic - Anachronism or Reality?]. Sekretar-referent [Secretary-Referent], no. 12. URL: https://www.profiz.ru/sr/12_2017/ charakteristika (accessed 2 March 2020).

Tokarev G.V., 2010. Dokumentnaya lingvistika [Documentary Linguistics]. Tula, Art-print Publ. $125 \mathrm{p}$.

Fedosyuk M.Yu., 1997. Nereshennye voprosy teorii rechevykh zhanrov [Unsolved Problems of the Theory of Speech Genres]. Voprosy yazykoznaniya [Topics in the Study of Language], no.5, pp. 102-120.

Khudominsky P.V., 1986. Razvitie sistemy povysheniia kvalifikatsii pedagogicheskikh kadrov sovetskoi obshcheobrazovatelnoi shkoly (1917-1981 gg.) [Development of the System of Advanced Training of Pedagogical Personnel of the Soviet Secondary School (1917-1981)]. Moscow, Pedagogika Publ. 182 p.

Shmeleva T.V., 1997. Model rechevogo zhanra [The Model of the Speech Genre]. Zhanry rechi [Speech Genres]. Saratov, Izd-vo Gosudarstvennogo uchebnonauchnogo tsentra «Kolledzh», pp. 88-98.

\section{SOURCES AND DICTIONARIES}

Kuznetsov S.A., ed. Bolshoy tolkovyy slovar russkogo yazyka [Big Explanatory Dictionary of the Russian Language]. Saint Petersburg, 1998. URL: http:/gramota.ru/slovari/info/bts (accessed 4 March 2020).

INFOUROK [Informational Lesson]. URL: https:// infourok.ru/predstavlenie-na-pervuyukvalifikacionnuyu-kategoriyu-2322411.html (accessed 4 March 2020).

Komprometiruyushchiy material na uchiteley Stalingradskoy oblasti, byvshikh na okkupirovannoy territorii [Compromising Material on Teachers of Stalingrad Region, Who Were in the Occupied Territory]. Gosudarstvennyy arkhiv Volgogradskoy oblasti [State Archive of Volgograd Region], f. 3423, inv. 3, dep. item 2, pp. 15-19.

Lichnye dela prepodavateley [Personal Files of Teachers]. Arkhiv GBPOU «Volgogradskiy stroitelnyy tekhnikum» 1970-1990 gg. [Archive of Volgograd Construction Technical School. 1970-1990].

Pedagogicheskoe soobshchestvo "UROK.RF» [Pedagogical Community "UROK.RF”]. URL: https://урок.pф/library/materiali dlya attestatcii/harakteristika_pedagoga (accessed 4 March 2020).

$U M K S P O$ [Learning Kit for Secondary Vocational Education]. URL: http://atestat.umk-spo.biz/ articles/zapdok/teorija/primer/primerxarrys (accessed 4 March 2020).

Videouroki.net. URL: https://videouroki.net/ razrabotki/kharaktieristika-uchitielia-nachalnykh-klassov.html (accessed 4 March 2020). 
O.А. Носачева. Динамика жанровых параметров документного текста (на материале характеристики)

\section{Information About the Author}

Olga A. Nosacheva, Candidate for a Degree, Department of Russian Philology and Journalism, Volgograd State University, Prosp. Universitetsky, 100, 400062 Volgograd, Russia, tronut3@mail.ru, https:/ /orcid.org/0000-0002-6733-7156

\section{Информация об авторе}

Ольга Александровна Носачева, соискатель кафедры русской филологии и журналистики, Волгоградский государственный университет, просп. Университетский, 100, 400062 г. Волгоград, Россия, tronut3@mail.ru, https://orcid.org/0000-0002-6733-7156 